\title{
SIMULATION OF A DEFECTLESS LIFECYCLE OF UNIQUE UNDERGROUND STRUCTURES OF THE SEWAGE SYSTEM AT THE STAGE OF THEIR CONSTRUCTION IN DIFFICULT SOIL CONDITIONS
}

\author{
Nickolai A. Perminov \\ Emperor Alexander I Saint-Petersburg State Transport University, Saint-Petersburg, RUSSIA
}

\begin{abstract}
Simulation of the parameters of a defectless lifecycle of large caissons at the stage of their plunging into heterogeneous soil milieu allows considerable expansion of the area of rational use of underground areas of megacities for deep transport facilities and engineering infrastructure due to provision of structural safety and sustainable operation of a special underground structure. Mega sizes of an RC caisson allow creating open underground areas, unique in volumes and deepness. The analysis of behavior of a massive gravitational fencing caisson at its incrementing and plunging into heterogenenous soil milieu allowed identifying the nature of its non-linear and unsteady behavior. Unsteadiness of the processes of interaction of a large structure and soil milieu accompanied by geometrical changeability causes the necessity to create methods of adaptive control of strainstress behavior of the system "gravitational large body - heterogeneous host medium" for decreasing aggravating influence of these effects on strength, deformability and reliability of the structure at the subsequent stages of its lifecycle. Due to joint step-by-step implementation of geotechnical and structural calculations a history of the processes of caisson-soil milieu interaction is modeled and the parameters of adaptive control of strain-stress behavior are predicted, thus providing conditions of controlled lowering. The paper demonstrates results of consistent implementation of the given concept at the lifecycle stages of the unique caissons for the sewage system of the megacity beginning from numerical modeling during design to computer models of control of strain-stress behavior of the system "large caisson - soil bulk" using the methods of geotechnology with subsequent monitoring provision of the defectless stage of construction.
\end{abstract}

Keywords: simulation, unique underground structure, heterogeneous soil milieu, geometrical changeability, non-linear models, control of strain-stress behavior of the system, structural safety, defectless lifecycle

\section{МОДЕЛИРОВАНИЕ БЕЗДЕФЕКТНОГО ЖИЗНЕННОГО ЦИКЛА УНИКАЛЬНЫХ ПОДЗЕМНЫХ СООРУЖЕНИЙ СИСТЕМЫ ВОДООТВЕДЕНИЯ НА СТАДИИ ИХ ВОЗВЕДЕНИЯ В СЛОЖНЫХ ГРУНТОВЫХ УСЛОВИЯХ}

\author{
Н.А. Перминов \\ Государственный университет путей сообщения Императора Александра I, г. Санкт-Петербург, РОССИЯ
}

Аннотация: Моделирование параметров бездефектного жизненного цикла крупногабаритных оболочек на стадии их погружения в неоднородные грунтовые среды позволяет за счет обеспечения конструкционной безопасности и устойчивого функционирования специального подземного сооружения существенно расширить область рационального использования подземного пространства мегаполисов для объектов транспортной и инженерной инфраструктуры . Мега размеры железобетонной оболочки позволяют создавать открытые подземные пространства уникальными по объемам и глубинами заложения. Анализ поведения массивной гравитационной ограждающей оболочки при постепенном ее наращивании и погружении в неоднородную грунтовую среду среды позволили выявить характер их нелинейного и нестационарного поведения. Нестационарность процессов взаимодействия массивного сооружения c грунтовой средой, сопровождаемая геометрической изменчивостью, вызывает необходимость создания методов адаптивного управления напряженно-деформированным состоянием системы «гравитационное крупногабаритное тело - неоднородная вмещающая среда» для уменьшения 
осложняющего влияния этих эффектов на прочность, деформируемость и надежность сооружения на последующих стадиях его жизненного цикла. Посредством совместного пошагового выполнения геотехнических и конструкторских расчетов моделируется история процессов взаимодействия оболочки с грунтовой средой и прогнозируются параметры адаптивного управления НДС системы, обеспечивая условия регулируемого погружения. В статье представлены результаты последовательной реализации изложенной концепции на стадиях жизненного цикла уникальных опускных сооружений системы водоотведения мегаполиса от численного моделирования при проектировании до компьютерных моделей управления с помощью методов геотехнологии напряженно-деформируемым состоянием системы «крупногабаритная оболочка - грунтовый массив» с последующим мониторинговым обеспечением бездефектной стадии строительства.

Keywords: моделирование, уникальное подземное сооружение, неоднородная грунтовая среда, геометрическая изменчивость, нелинейные модели, управление напряженно-деформируемым состоянием системы, конструкционная безопасность, бездефектный жизненный цикл.

\section{NON-LINEAR AND UNSTEADY PROCESSES OF INTERACTION OF A LARGE CAISSON IN THE CONDITIONS OF SIMULTANEOUS INCREMENTING AND PLUNGING OF THE STRUCTURE}

Characteristic parameters and indicators, according to which underground structures of the sewage system of large cities can be regarded as the unique ones, first and foremost, include abnormal depth of more than $70 \mathrm{~m}$ as well as a high degree of requirements to their ecological safety. Special requirements to preservation of structural integrity during longtem exploitation should be set for these structures as particulary dangerous facilities accumulating and transporting agressive sewage discharge through their internal culverts under residential urban areas.

Structural integrity of an underground sewage structure means the capacity of its resistance to decrepit and corrosive damages at all stages of its lifecycle. One can achieve these conditions only by means of joint gradual solution of geotechnical and structural problems when prelimit stress-strain states of an RC culvert during its interaction with a soil bulk are modeled and predicted at the stage of design of its life cycle, then using the methos of geotechnology and monitoring they are provided at the stage of construction of a structure, and later applying the same or modified monitoring system they are supported at the stage of long-term operation under the conditions of technically generated effects. There is a need to consider another factor which defines the category of structure uniqueness as a particular and specific one. It implies limited or complete unavailability of repair of underground structures of this type. Firstly, it is associated with the fact that according to the present schemes of sewage, which exist in megacities nowadays, these facilities cannot virtually be put out of operation without a threat of violating sustainment of the city engineering infrastructure.

Therefore, in order to provide safe and sustainable operation of large underground structures of the sewage system it is necessary to provide internal integrity of fencing structures with high degree of water resistance at all stages of their lifecycle.

The existing norms and sets of regulations envisage verification calculations of caisson underground structures for the stages of construction and exploitation. However for large-size caisson structures due to specific conditions of their interaction with a soil bulk and inclusion the large scale effect (factor): according to hyper sizes of the area of lateral surface of a culvert interacting with heterogeneous soil and a super large weight, which creates a powerful kinetic impulse at instant, often sudden drops of a caisson structure, joint manifestation of these factors causes specific non-linear behavior of the structure at its driving and the embedding soil 
Simulation of Defectless Lifecycle of Unique Underground Structures of the Sewage System at the Stage of Their Construction in Difficult Soil Conditions

bulk. Strength and deformability of a large-size massive structure, its geometrical variability should be calculated not only for the final stage of construction but also for a whole history of driving considering a history of caisson-soil bulk interaction at driving, and, consequently the effect of gradual inheritance of stress-strain state, that is possible to make only using solutions of non-linear problems, non-linear models and computer non-linear simulation.

The analysis of test and experimental results presented in the paper showed that the main defects leading to violation of culvert integrity and crack occurrence emerged in the period of construction of the underground part in the soil bulk. Therefore, the main task is reduced to provision of operation of a structure at pre-limit states at the stage of construction of its lifecycle. In order to implement these conditions the decisive role is played by evaluation of real work of structures with account of the process of their gradual construction in the soil bulks and non-linear properties of structural materials and soil. Consideration of these conditions allows constructing an adequate model of the process of culvert interaction at its stage-bystage embedment into the soil bulk. Calculation substantiation of a range of pre-limit changes of the stress-strain state of a megamassive culvert at its embedment into heterogeneous soils provides defectless operation of the lifecycle of an underground structure at the stage of its construction [1]. The analysis of the processes of caisson loading at the stage of its construction with account of the effect of inherited stress-strain behavior allows creating an adequate calculation-analytical model of an underground structure and selecting a rational method of calculation to predict dynamics and spatial borders of changing stress-strain state of an $\mathrm{RC}$ caisson structure providing defectlessness of the structure at all stages of its driving.

The methodological approach proposed in the paper allows transferring from the earlier accepted methods of calculation of underground sewage caisson structures to the concept of simulation and prediction of defectless lifecycle at the stage of construction. The results of experimental and theoretical research, which are given in the paper, substantively prove that modeling and calculative substantiation of schemes and parameters of preventive protection of an underground structure at the stage of its construction using geotechnical methods provides its safety and resistance against technically generated impacts at the subsequent stages of the lifecycle during its long-term regime operation.

\section{THE ANALYSIS OF INTERACTION OF A LARGE CAISSON WITH HETEROGENEOUS SOIL MILIEU AT THE STAGE OF ITS PLUNGING}

In order to provide stable and safe operation of large caisson structures there is a need to ensure internal integrity of fencing structures with high degree of waterproofness at all stages of their life cycle.

The existing standards [1] and regulations [2] envisage checking calculations of underground structures to be lowered for the stages of their construction and operation. However, based on the experience one can say that in case of large caisson structures it is not enough due to specific conditions of their interaction with a soil bulk and inclusion the effect (factor) of a large scale: hyper sizes of an area of lateral surface of the shell, which interacts with heterogeneous soil, and its super large weight, which creates a powerful kinetic impulse during instant, often sudden subsidence, cause a beyond-design situation for a caisson structure. Joint actions of these factors stipulate specific non-linear behavior of the structure at lowering as well as the host soil bulk. 


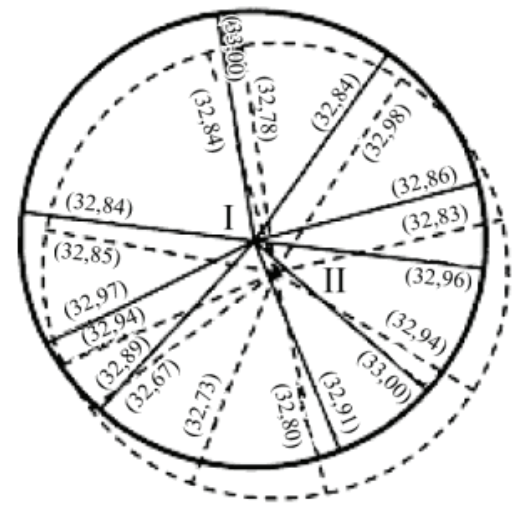

a)

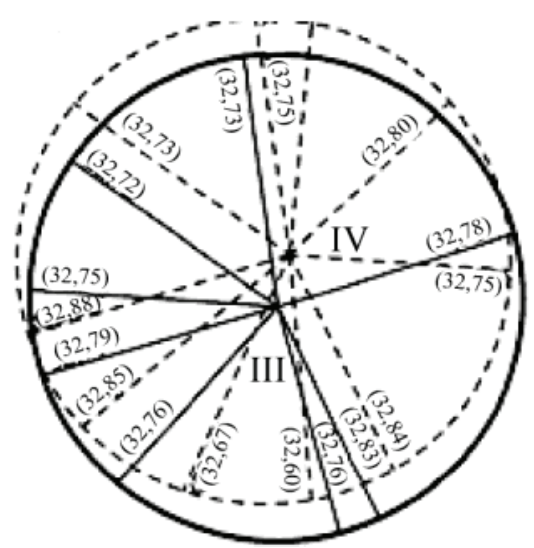

b)

Figure 1. The measurement of a radius $R$ and displacement of the center of circle $O$ during its lowering to a depth $H: a, b$-respectively $I$-for $H=17 \mathrm{~m}$; II-for $H=29 \mathrm{~m}$; III-for $H=25 \mathrm{~m}$; $I V-$ for $H=29 \mathrm{~m} ; O(I-I I)=0.108 \mathrm{~m} ; O(I I I-I V)=0.234 \mathrm{~m}$.

Due to strength and deformability of the large massive structure, its geometric changeability it is necessary to calculate not only the final stage of construction but also the whole history of lowering taking into account a history of the process of shell-soil bulk interaction during caisson lowering and, consequently, the effect of gradual inheritance of stress-strain behavior. These problems could be solved only by tackling non-linear problems, non-linear models and computer non-linear simulation [3,4,5].

The analysis of the results of in situ and calculation-experimental works and the data of the comprehensive system of geotechnical monitoring (fig. 1) of lowering large shells showed the features of their interaction with heterogeneous soil milieu [6]. The geotechnical profile for the monitored facilities is characterized as follows: the upper layer is represented by Quaternary strata down to the depth of 14.0-25.0 m (saturated silty sands of medium density, $\mathrm{E}=11 \mathrm{MPa}, \mathrm{C}=0 \mathrm{MPa}, \varphi=$ $30^{\circ}$; plastic silty clayey sands, $\mathrm{E}=4 \mathrm{MPa}, \mathrm{C}=$ $0.01 \mathrm{MPa}, \varphi=15^{\circ}$; liquid-plastic silty sandy clays, $\mathrm{E}=9 \mathrm{MPa}, \mathrm{C}=0.025 \mathrm{MPa}, \varphi=16^{\circ}$; semi-solid silty sandy clays with gravel and pebbles, $\mathrm{E}=14 \mathrm{MPa}, \mathrm{C}=0.028 \mathrm{MPa}, \varphi=28^{\circ}$ ), the lower level represents the bed of dislocated solid Proterozoic clays $(\mathrm{E}=19 \mathrm{MPa}, \mathrm{C}=$ $\left.0.04 \ldots 0.06 \mathrm{MPa}, \varphi=18 \ldots 21^{\circ}\right)$.

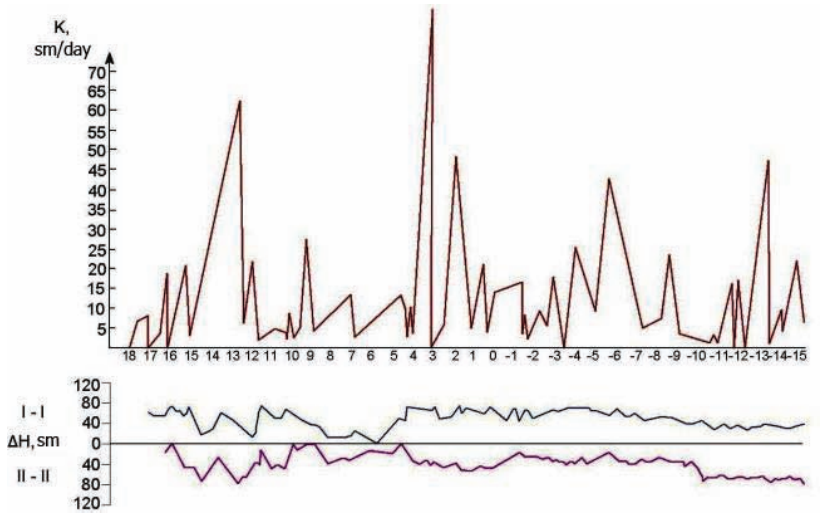

b)

Figure 2. Graphs of shell lowering: $a-D=51 \mathrm{~m}, H=53 \mathrm{~m}(1-$ tilt graph; 2 - an elevation of lower plane; 3 - soil elevation; 4 - increase of shell weight); $b$-the diagram of deviation of the shell from the vertical axis. 
Simulation of Defectless Lifecycle of Unique Underground Structures of the Sewage System at the Stage of Their Construction in Difficult Soil Conditions

The monitoring identified a very important phenomenon: the peak values of horizontal stresses exceed the calculation values $2.3-2.5$ times, and it is observed at deviation of the shell from the vertical axis and changes of its geometry (Figure 1,2). It can be the reason of suspension of the process of lowering the massive shell with a subsequent sudden, conditionally instant drop. Based on the analysis of the graph of lowering (fig. 2a) it can be seen that a value of drop reaches $1.5 \mathrm{~m}$ and more. The shell structure takes impact beyond-design loads by creating a powerful kinetic impulse by its drop to the soil bulk of a pit bottom [7], that can cause occurrence of microcracks in concrete of the structure and inevitably leads to violation of the structural hydro insolation. This phenomenon has been identified after 10-15year-long operation of the gas and pumping station complex of the water treatment facilities of St. Petersburg [8].

Geomonitoring showed unsteadiness of the processes of interaction of the external contour of the massive structure [9]. Complex and, as a rule, uncontrolled character of the processes during conditionally instant embedment of the shell into the host heterogeneous milieu as well as the environment, that has physical and genetic non-linearity [10], demonstrate that the study of stain-stress behavior of the shell and soil bulk can be carried out only on the basis of computer modeling of this process using geotechnical and structural software complexes.

\section{THE SIMULATION OF CONDITIONALLY INSTANT DROPS OF THE MASSIVE SHELL DURING ITS LOWERING INTO HETEROGENEOUS SOIL MILIEU}

The analysis of behavior of the caisson structure during its sudden uncontrolled sliding (drop) to the bottom of an open soil cavern from the height $1.3-1.5 \mathrm{~m}$ with the angles of deviation from the vertical axis $0.5^{\circ}-5^{\circ} \mathrm{C}$ was conducted with a help of the software complex Autodesk Robot Structural Analysis Professional [11].

While developing the calculation model (figure 3 ) it was considered that the shell structure consists of two cylinders, one stands on the other: the upper cylinder: the external radius $\mathrm{R}$ $=36 \mathrm{~m}$, the internal radius $\mathrm{R}=30.5 \mathrm{~m}$, the height $\mathrm{H} 1=46 \mathrm{~m}$; the lower cylinder: the external radius $\mathrm{R}=36 \mathrm{~m}$, the internal radius $\mathrm{R}=$ $30 \mathrm{~m}$, the height $\mathrm{H} 2=25 \mathrm{~m}$. Therefore, the external diameter of the shell was $\mathrm{D}=72 \mathrm{~m}$, the height of the shell was $\mathrm{H}=71 \mathrm{~m}$. Concrete grade - B30.

In order to simulate a value of impact force at dropping the shell in the model the cylinder fell from the height $\mathrm{H}=150-250 \mathrm{~cm}$ under the action of its own weight with the tilt angle $0.5^{\circ}$ $5^{\circ}$ to a flexible soil (green-gray clay: $\varphi=21^{\circ}, \mathrm{C}$ $=0.04 \mathrm{MPa}, \mathrm{E}=19 \mathrm{MPa})$. A spatial calculation scheme of the shell was modelled: the weight $\mathrm{G}$ $=210000$ tons; the amount of nodes 16944; the amount of volumetric finite elements 12496; the amount of static degrees of freedom 50828; the amount of loadings 27; the acceleration of gravity $\mathrm{g}=9.81 \mathrm{~m} / \mathrm{kV} . \mathrm{s}$; the time of drop

$$
t=\sqrt{2 * H / g}
$$

$\Delta t=0.30-0.54$ s. Due to the tilt angle friction forces were applied in the upper part of the caisson from one side and in the lower part from the opposite one.

As the simulation of the processes of drop at different angles of deviation of the shell from the axis $-\mathrm{a}$ and falling heights $-\Delta \mathrm{H}$ was made in quite a large range, table 1 gives only the most typical results, which were taken for the analysis. The total calculation table of the results of integration of motion equation for the shell during the drop (falling) at speeds VZ, VX, VY $(\mathrm{cm} / \mathrm{s})$, acceleration AZ, AX, $\mathrm{AY}(\mathrm{cm} / \mathrm{s} 2)$ and displacements UZ, UX, UY (cm) included 186385 lines. 

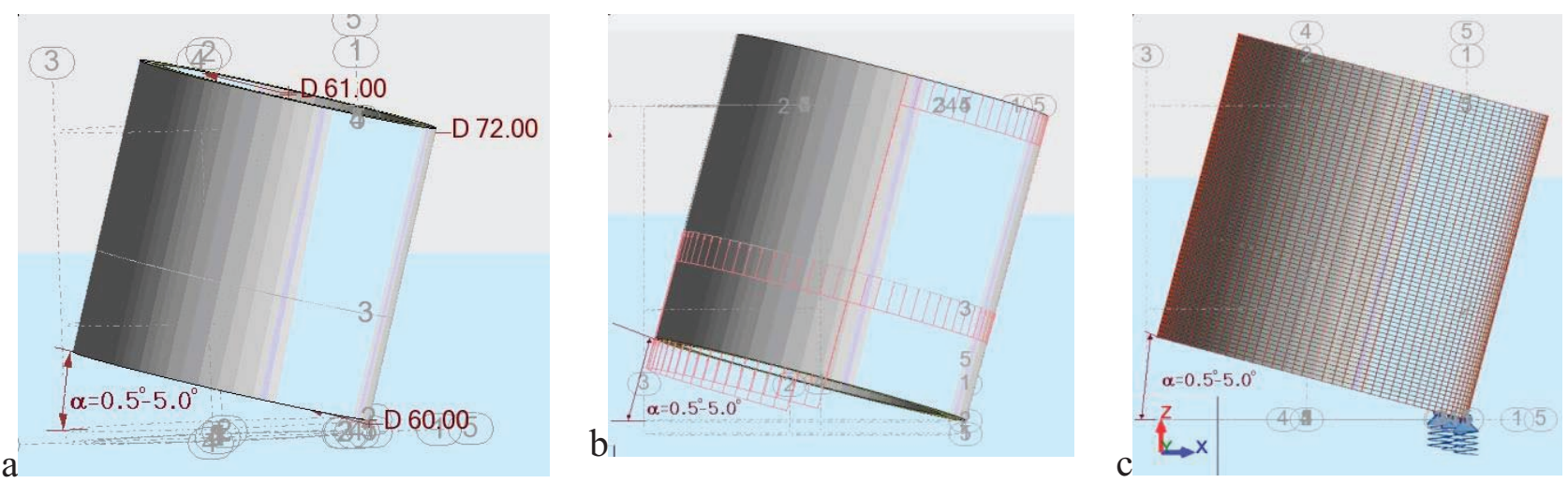

Figure 3. The schemes of calculation models of the lowered shell at different angles of its deviation from the vertical axis: a- static support at tilt; $b, c$ - drop and sliding at tilt (deviation from the vertical axis).

Table 1. The simulation results.

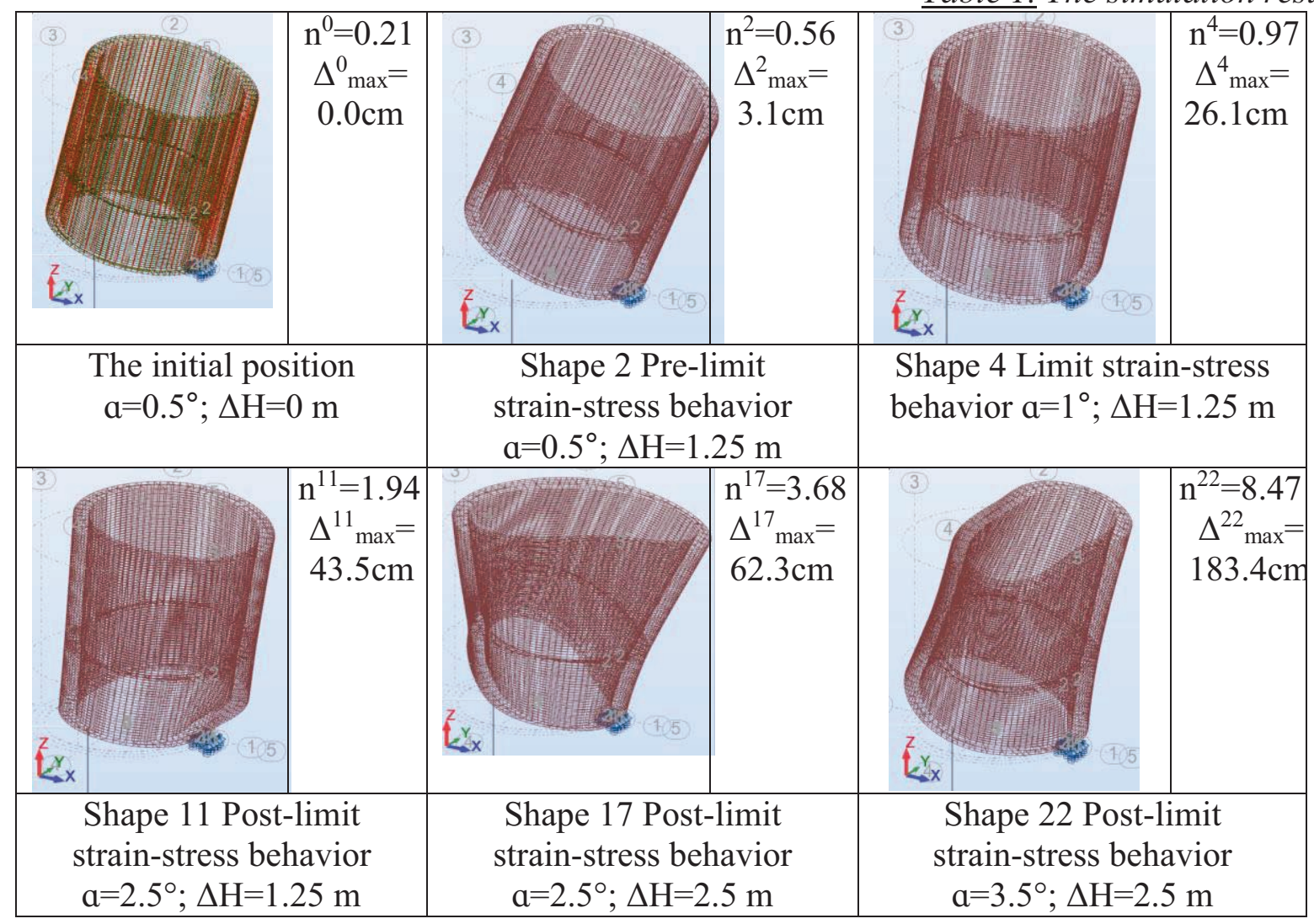

Based on the simulation results (Figure 4) there were set admissible parameters of spatial location of the shell and the ranges of its conditionally instant drops, which provide prelimit strain-stress behavior of the shell.
The simulation results show that for the large shell the recommendations of regulatory documents [12] have limited application and are needed to be confirmed via calculative modeling. 
Simulation of Defectless Lifecycle of Unique Underground Structures of the Sewage System at the Stage of Their Construction in Difficult Soil Conditions

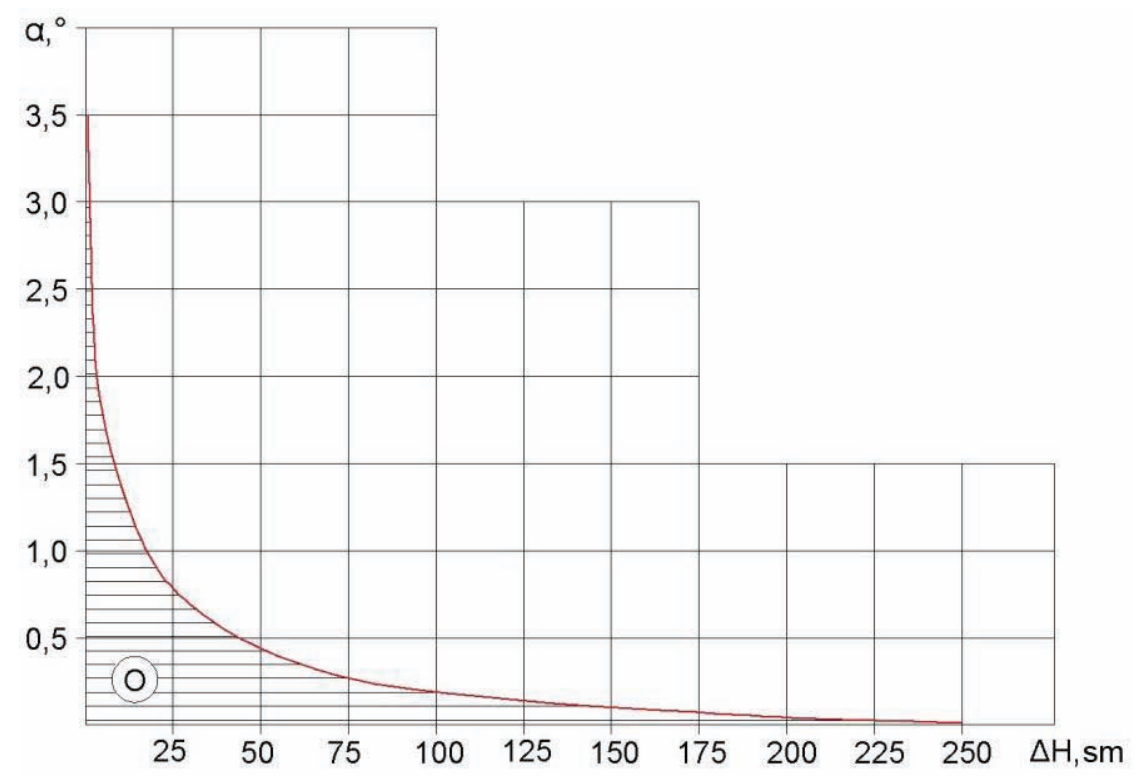

Figure 4. The area of limit admissible values of conditionally instant drops $\Delta H$ of the shell, $D=61 \mathrm{~m}$, height $H=71 \mathrm{~m}$, weight $G=210000$ tons, at different angles of deviation of the structure from the vertical axis $a^{\circ}$ (Concrete B30; $\varphi=21^{\circ}, C=0.04 \mathrm{MPa}, E=19 \mathrm{MPa}$ ).

4. THE SIMULATION OF CONTROLLED REGIMES OF LOWERING THE MASSIVE SHELL INTO A SOIL OF DIFFERENT STRENGTHS USING THE METHODS OF

\section{GEOTECHNOLOGY}

Taking into account the results of the previous steps of modeling, at this stage the problem of geotechnical simulation of the process of lowering the shell into the soil bulk in a controlled mode was solved. The geotechnical methods served as external impacts on the "shell-soil bulk" system.

An incremental model of deformation type was used as the calculation soil model for solving the non-linear problem. A stress-strain connection in the model was taken separately for volumetric and shear components of a stress tensor

$$
\left.\begin{array}{c}
d S_{i j}=2 G^{T} \cdot d e_{i j} \\
d \delta_{c p}=3 K^{T} \cdot d \xi_{c p}
\end{array}\right\}
$$

where: $d S_{i j}$ and $d e_{i j}$ are increments of deviatoric components of stress and strain tensors, respectively; $d \delta_{c p}$ and $d \xi_{c p}$ are increments of average stress and strain; $G^{T}$ and $K^{T}$ - tangent moduli of deformation of shape and volume.

Tangent moduli of deformation $G^{T}$ and $K^{T}$ were approximated according to linear polynomial of the second degree with one variable:

$$
\left.\begin{array}{c}
G^{T}=G\left(S_{i j} ; \delta_{\mathrm{cp}}\right)=A_{0}+A_{1} \delta_{c p}+A S_{i j} \\
K^{T}=K\left(\delta_{c p}\right)=B_{0}+B_{1} \delta_{c p}+B_{2} \delta_{c p}^{2}
\end{array}\right\}
$$

Approximating dependencies (2) are experimentally substantiated on the example of stabilometer triaxial tests (STT) [1,2].

The model considers the conditions of loading and unloading according to the following criteria:

$$
\left.\begin{array}{c}
\text { loading - } d S_{i j}>\varnothing ; d \delta_{c p}>\varnothing \\
\text { unloading - } d S_{i j}<\varnothing ; d \delta_{c p}<\varnothing
\end{array}\right\}
$$


In order to fulfill the condition of "loading" tangent moduli $K_{H}^{T}$ and $G_{H}^{T}$ were calculated according to formulae (2) in compliance with the current stress-strain behavior. For fulfilling the condition of "unloading" $K_{P}^{T}$ and $G_{P}^{T}$ were defined according to other dependencies (4).

$$
K_{P}^{T}=\text { const } ; \mathrm{G}_{\mathrm{P}}^{\mathrm{T}}=A_{0}+A_{1} \delta_{c p}
$$

The parameters of the calculation model A0; A1; A2; Kp; B0; B1; B2 were defined based of the data of STT. The medium-grained sandy soil of the density $\mathrm{Pd}=1.65 \mathrm{~g} / \mathrm{cm} 3$ and water content $\mathrm{W}=10 \%$ was used as the tested soil. All calculations were made using the numerical method of finite elements with a help of geotechnical software "PCK". The procedure of solving the non-linear problem was reduced to the well-known method of variable rigidity [13], according to which the matrix of rigidity was transformed at each step of the solution in accordance with the current level of stress-strain behavior and orientation of the vector of additional loading.

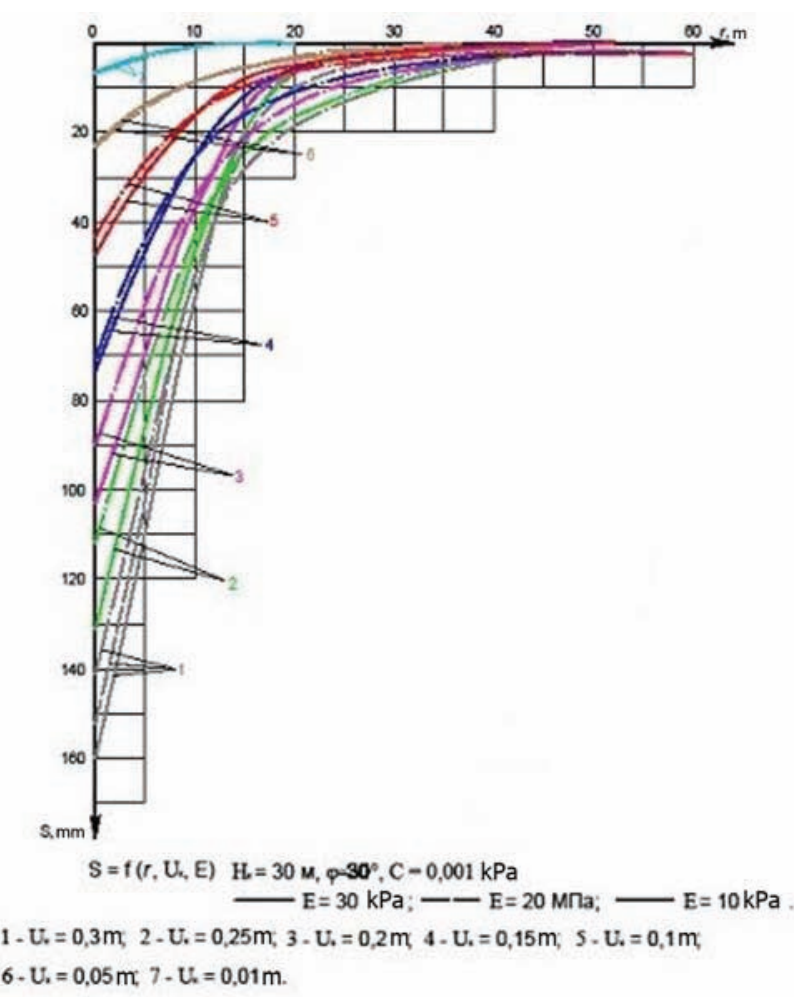

b)

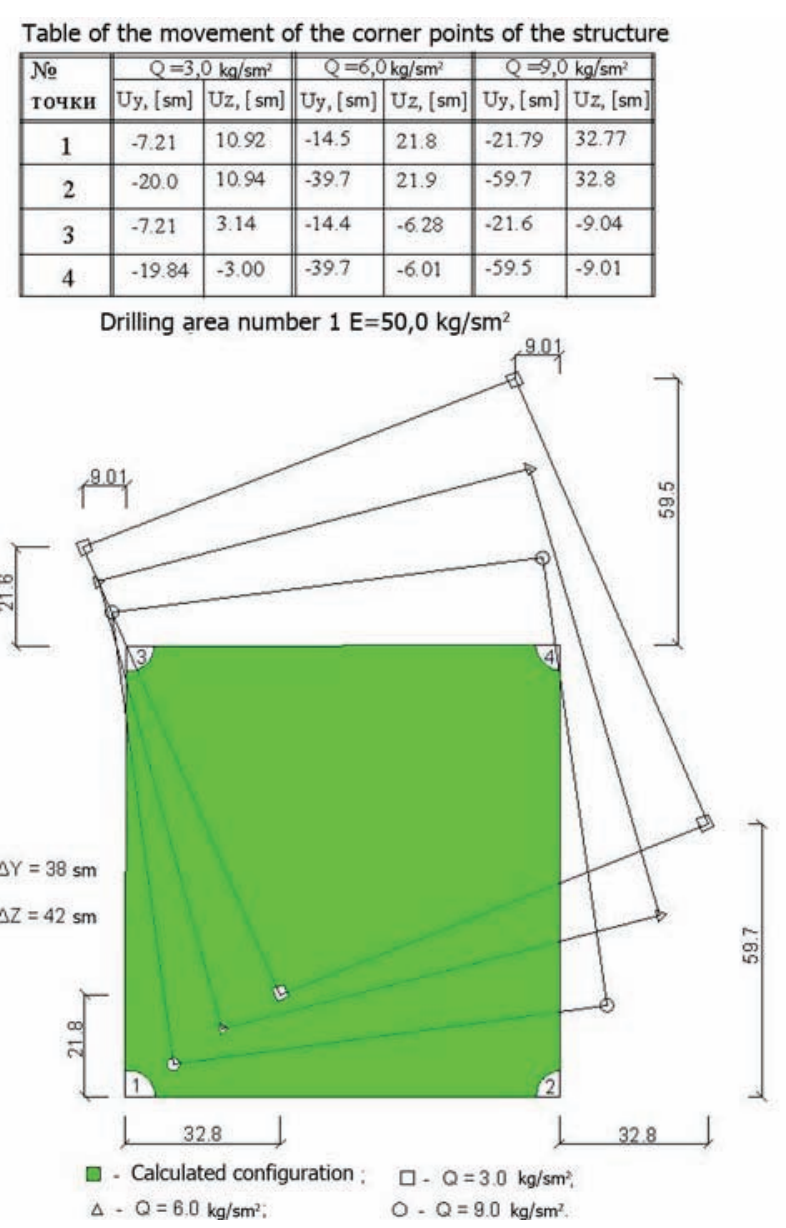

a)

Figure 5. The displacement of the shell contour in continuous milieu: $a$ - at correction of tilt under the conditions of action of a lateral additional load $Q=0.3-0.9 \mathrm{MPa} ; b-$ the influence of a value of the shell contour displacement Ux on settlements of the soil surface at correction of tilt.

Figure 5a shows a characteristic graph of the shell contour displacement to the design position with inclusion of a geotechnical impact on strain-stress behavior of the surrounding soil 
Simulation of Defectless Lifecycle of Unique Underground Structures of the Sewage System at the Stage of Their Construction in Difficult Soil Conditions

bulk into the calculation. The results of simulation show (Figure $5 \mathrm{~b}$ ) that rectification of the shell contour displacement almost to the design position (from $32.8 \mathrm{~cm}$ to $9.01 \mathrm{~cm}$ ) allows decreasing an area of distribution and a

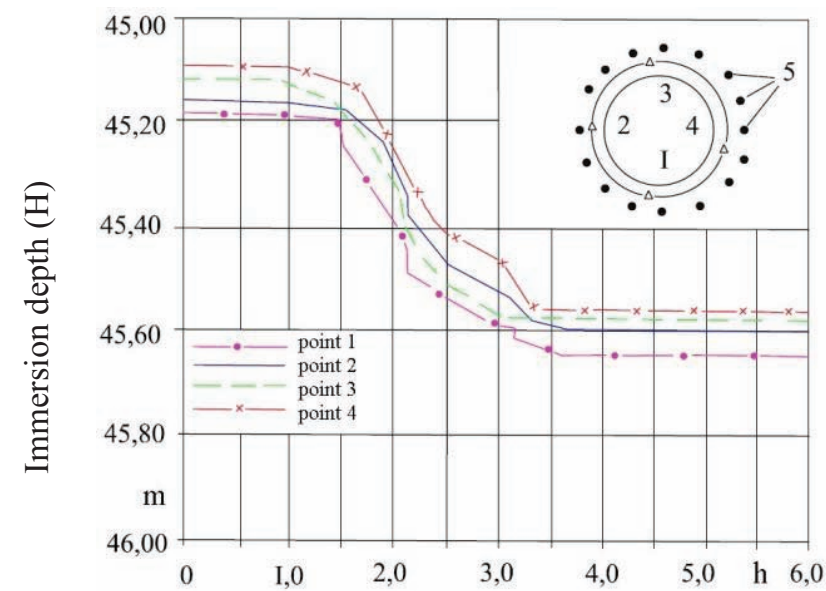

a

Duration of electrical treatment (Тэ) value of settlement of the soil bulk around the shell several times (the area of distribution reduces from $45 \mathrm{~m}$ to $9 \mathrm{~m}$; the value of settlement, respectively, from $150 \mathrm{~cm}$ to $8 \mathrm{~cm}$ ).

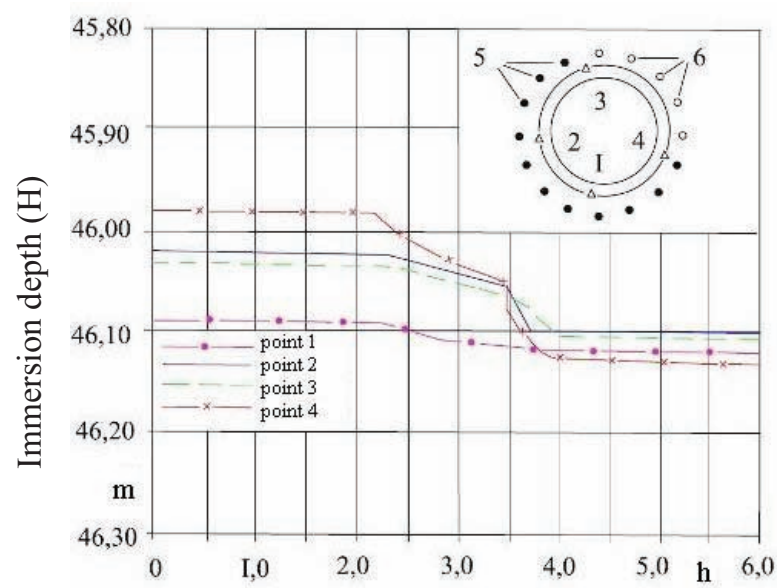

b

Duration of electrical treatment (Тэ)

Figure 6. Electroosmosis deeping diagram phragments: a - even deeping; $b$ - bank correction; 1,2,3,4 - fixed points; 5,6 - electrodes (catodes and anodes).

The control of strain-stress behavior of the system "large caisson - heterogeneous host medium" to provide structural safety of an RC structure in the range of design parameters $[4,7]$ is achieved with a help of the methods of geotechnology [8], which are accompanied by the interactive system of monitoring of the lifecycle at the stage of construction. Figure 6

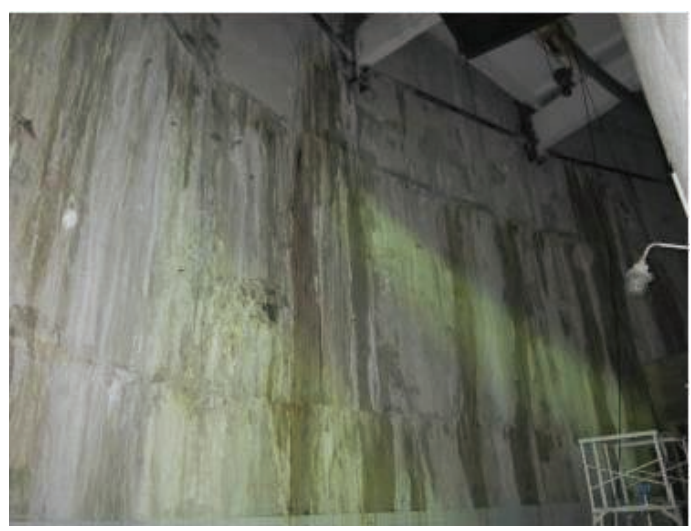

a

Figure 7. Examples of defectless and defective lifecycles of caissons at the stage of operation: $a-$ 'in the conditions of simulation and monitoring of the plunging process, $b-$ without simulation of the process at the drop of structures. shows the graphs of defectless plunging of a large $57-\mathrm{m}$ caisson at the elevation of $46 \mathrm{~m}$ in the mode of electroosmosis-controlled lowering into heterogeneous soils $(\mathrm{E} 1=45 \mathrm{MPa}$; 2 2 = $240 \mathrm{MPa})$, which calculation regimes were elaborated on the basis of step-by-step computer modeling.

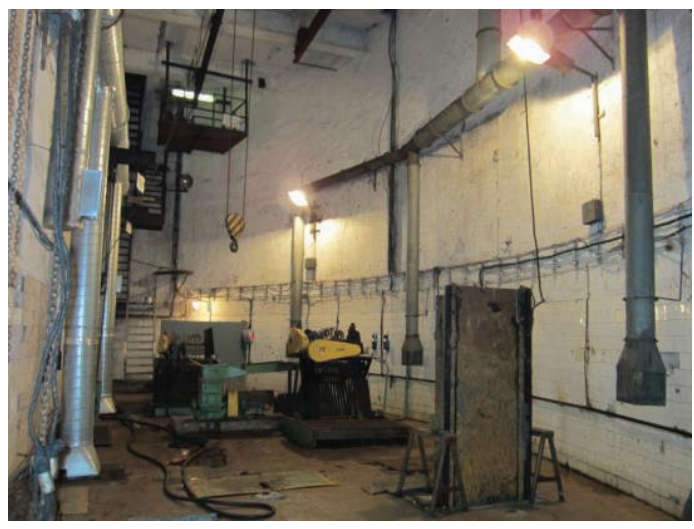

$\mathrm{b}$ 
The defectless lifecycle of a large massive caisson at the stage of its construction is demonstrated by its integrity and water resistance of its structure after long-term operation (fig.7a, b). Fig.7a and fig.7b - show comparatively a caisson which was plunged into heterogeneous soils without geotechnical support. Both long-operating structures belong to the system of underground sewage facilities.

\section{CONCLUSIONS}

The analysis of behavior of the massive gravitational fencing shell during its gradual increasing and lowering into the heterogeneous soil milieu allowed identifying a number of factors, which characterize its non-linear behavior in the conditions of joint interaction.

Physical non-linearity is caused by behavior in the elasto-plastic area of the soil bulk, which contacts with the lateral surface, during deviation of the structure from the vertical axis. Geometric non-linearity manifests itself when its geometry changes asymmetrically during instant-stepwise drops of the massive shell.

Unsteadiness of the processes of interaction of the massive structure with the soil milieu as well as itself causes the necessity of creating methods of adaptive control of the stress-strain behavior of the system "gravitational large body - heterogeneous host milieu".

Due to joint step-by-step making geotechnical and structural calculations a history of the processes of shell-soil milieu interaction is simulated, the parameters of the adaptive control of the system of strain-stress behavior, which are implemented with a help of external geotechnical impacts at the stage of construction of the structure, are predicted.

The results of the considered concept are applied at geotechnical support of a lifecycle of the unique underground structures of the sewage system of St. Petersburg at the stage of construction of large caisson shells during simultaneous lowering and increasing of the structure.

\section{REFERENCES}

1. Perelmuter A.V. The Formation and Development of Concepts About the Design Scheme of Structures. // International Journal for Computational Civil and Structural Engineering, 2018, Volume 14, Issue 4, pp. 109-129

2. Ilichev V.A. and Mangushev R.A. Spravochnik Geotehnika. Osnovanija, Fundamenty i Podzemnye Sooruzhenija [The Reference Book of a Geotechnical Engineer. Soils, foundations and underground structures]. Moscow, ASV Publishing House, 2016, 1034 pages (in Russian).

3. SP 43.13330.2012. Sooruzhenija Promyshlennyh Predprijatij [Structures of Industrial Enterprises]. An updated version. Construction Code 2.09.03-85. Moscow, National standard, 2012, 101 pages (in Russian).

4. Perminov N.A. Unsteady Interaction Simulation of a Large RC Shell With Heterogeneous Soil Milieu for a Gradually Increasing Caisson Structure. // IOP Conf. Ser.: Mater. Sci. Eng., 2018, Vol. 465, 012059.

5. Barabash M.S. Modelirovanie Zaproektnyh Vozdejstvij pri Issledovanii Zhiznennogo Cikla Konstrukcij Zdanij i Sooruzhenij [Simulation of Beyond-Design Impacts at Studying the Lifecycle of Buildings and Structures]. // International Journal for Computational Civil and Structural Engineering, 2016, Volume 12, Issue 3, pp. 15-25 (in Russian).

6. Ilichev V.A. Ploskaja Zadacha o Shtampe na Uprugom Osnovanii $\mathrm{s}$ Uchetom Tehnologii Ego Vozvedenija [A Flat Problem of a Plate on Elastic Subsoil With Account of a Technology of its Construction]. // Soils, Foundations and Soil Mechanics, 2008, Volume 4, pp. 12-16 (in Russian).

7. Perelmuter A.V., Kabantsev O.V. Analiz Konstrukcij s Izmenjajushhejsja Raschetnoj 
Simulation of Defectless Lifecycle of Unique Underground Structures of the Sewage System at the Stage of Their Construction in Difficult Soil Conditions

Shemoj [The Analysis of Structures With a Changing Calculation Scheme]. Moscow, SCAD Soft, ASV Publishing House, 2015, 148 pages (in Russian).

8. Perminov N.A. Comprehensive Geotechnical Support for the Construction of Large Edifices as a Part of St. Petersburg. // Geotechnical Engineering for the Preservation of Monuments and Historic Sites (Viggiani (ed.) Balkema, Rotterdam, 1997, pp. 1074-1081.

9. Perminov N.A., Perminov A.N. Geotehnicheskie Aspekty Obespechenija Bezopasnosti Dlitel'no Jekspluatiruemyh Ob\#ektov Inzhenernoj Infrastruktury Krupnyh Gorodov v Slozhnyh Gruntovyh Uslovijah [Geothermal Aspects of Providing Safety of Long-Operating Facilities of Engineering Infrastructure of Large Cities in Difficult Soil Conditions]. // The Journal of Perm Research University, 2014, Volume 4, pp. 111-128 (in Russian).

10. Perelmuter A.V., Slivker V.I. Raschetnye Modeli Sooruzhenij i Vozmozhnost' ih Analiza [Calculation Models of Structures and a Possibility of Their Analysis]. Moscow, SCAD Soft, DMK Press Publishing House, 2011, 710 pages (in Russian).

11. SP 22.13330.2016 Osnovanija Zdanij i Sooruzhenij [Foundations of Buildings and Structures]. An updated version. Construction Code 2.02.01-83*. Moscow, National standard, 2016, 172 pages (in Russian).

12. Carmody Y., Sterling R.L. Underground space design. A guide to subsurface utilization and design for people in underground spaces. New York, VNR, 1993, 328 pages.

13. Ponomaryov A.B., Kaloshina S.V., Zakharov A.V., Bezgodov M.A., Shenkman R.I., Zolotozubov D.G. Results of Geotechnical Modeling of the Influence of Construction of the Large Foundation Ditch on the Existing Historical Building. // Japanese Geotechnical Society Special
Publication: The 15th Asian Regional Conf. on Soil Mechanics and Geotechnical Engineering: Geotechnical Heritage. Part 2 (TC 301/ATC 19 Session) Volume 78, 2015, pp. 2676-2679.

\section{СПИСОК ЛИТЕРАТУРЫ}

1. Perelmuter A.V. The Formation and Development of Concepts About the Design Scheme of Structures. // International Journal for Computational Civil and Structural Engineering / Международный журнал по расчету гражданских $u$ строительных конструкиий), 2018, Volume 14, Issue 4, pp. 109-129.

2. Ильичев В.А. и Мангушев Р.A. Справочник геотехника. Основания, фундаменты и подземные сооружения. М.: Издательство АСВ, 2016. - 1034 с.

3. СП 43.13330.2012 Сооружения промышленных предприятий/ Актуализированная редакция. СНиП 2.09.03-85. - М.: Национальные стандарты, 2012. - 101 с.

4. Perminov N.A. Unsteady Interaction Simulation of a Large RC Shell With Heterogeneous Soil Milieu for a Gradually Increasing Caisson Structure. // IOP Conf. Ser.: Mater. Sci. Eng., 2018, Vol. 465, 012059.

5. Барабаш М.С. Моделирование запроектных воздействий при исследовании жизненного цикла конструкций зданий и сооружений. // International Journal for Computational Civil and Structural Engineering / Международный журнал по расчету гражданских и строчтельных конструкций), 2016, Volume 12, Issue 3, pp. 15-25.

6. Ильичев В.А. Плоская задача о штампе на упругом основании с учетом технологии его возведения. // Основания, фундаменты и механика грунтов, 2008, №4, c. 12-16. 
7. Перельмутер А.В., Кабанцев О.В. Анализ конструкций с изменяющейся расчетной схемой. - М.: СКАД СОФТ Издательство АСВ, 2015. - 148 с.

8. Perminov N.A. Comprehensive Geotechnical Support for the Construction of Large Edifices as a Part of St. Petersburg. // Geotechnical Engineering for the Preservation of Monuments and Historic Sites (Viggiani (ed.) Balkema, Rotterdam, 1997, pp. 1074-1081.

9. Перминов Н.А. и Перминов А.Н. Геотехнические аспекты обеспечения безопасности длительно эксплуатируемых объектов инженерной инфраструктуры крупных городов в сложных грунтовых условиях. // Вестник ПНИПУ. Строительство и архитектура, 2014, №4, с. 111-128.

10. Перельмутер А.В., Сливкер В.И. Расчетные модели сооружений и возможность их анализа. - М.: СКАД СОФТ, Издательство ДМК Пресс, 2011. $710 \mathrm{c}$.

11. СП 22.13330.2016 Основания зданий и сооружений / Актуализированная редакция. СНиП 2.02.01-83*. - М.: Минстрой России, 2016. - 172 с.

12. Carmody Y. and Sterling R.L. Underground space design. A guide to subsurface utilization and design for people in underground spaces. New York, VNR, 1993, 328 pages.

13. Ponomaryov A.B., Kaloshina S.V., Zakharov A.V., Bezgodov M.A., Shenkman R.I., Zolotozubov D.G. Results of Geotechnical Modeling of the Influence of Construction of the Large Foundation Ditch on the Existing Historical Building. // Japanese Geotechnical Society Special Publication: The 15th Asian Regional Conf. on Soil Mechanics and Geotechnical Engineering: Geotechnical Heritage. Part 2 (TC 301/ATC 19 Session) Volume 78, 2015, pp. 2676-2679.
Nicolay A. Perminov, C.T.Sc., Chief specialist of the Institute SUE "Lengiproingproekt", docent «Emperor Alexander I St. Petersburg State Transport University», 9, Moskovsky prospect, St. Petersburg, 190031, Russia; phone +7 (812) 315-26-21; fax: +7 (812) 315-26-21;

E-mail: perminov-n@mail.ru.

Перминов Николай Алексеевич, кандидат технических наук, главный специалист института ГУП «Ленгипроинжпроект», доцент «Петербургского государственного университета путей сообщения Императора Александра I»; 190031, Россия, г. СанктПетербург, пр. Московский, д. 9, тел. +7 (812) 315-2621; факс +7 (812) 315-26-21;

E-mail: perminov-n@mail.ru. 